\title{
Impact Analysis of Developed Managerial Intervention Package
}

\author{
Madhuri Kulkarni*, Jayashri Rodge and Manjusha Revanwar \\ Department of Community Science, VNMKV, Parbhani - 431 402, M.S., India \\ *Corresponding author
}

Keywords

Training needs, Managerial skills, Managerial intervention package

Article Info

Accepted: 12 May 2021 Available Online: 10 June 2021

\section{A B S T R A C T}

Managerial problems of each household are different and it does not have readymade answer. Hence the women in India have to struggle in utilizing her managerial skill in managing the family resources. All women are not born with managerial skills and have to learn through observation and training. The present investigation was carried out in four villages i.e. Nandkheda, Brahmangaon, Sayala and Lohagaon of Marathwada region. A total sample of 100 women 25 each from four villages were selected randomly. The objectives of the study were to identify the problems and training needs of rural women with regard to household managerial skills. It can be concluded from the study that the rural women face the problem in managing family resources and need training help to empower themselves with managerial skills in selected areas of household management. In second phase the need based training module was developed and training programmes were conducted. Impact analysis of intervention package showed improvement in managerial skill of rural home makers.

\section{Introduction}

Household management is of fundamental importance for wellbeing of people. It is the major means of achieving the family goals. Gross and Crandall describe home management in simplest term as using what you have to get what you want. What the family has consists of the resources of family members. Besides time, energy, money and other material goods, family resources also include knowledge, interests, abilities, skills, attitudes of family members and community facilities. Home management is a mental process and involves three steps of planning, controlling and evaluating. The use of family resources has to be planned and controlled.

In doing this the family has to solve numerous problems and make decisions all the time (Mann, 1984). Since time memorable the role of women in household management is 
prominent. Managerial problems of each household are different and it does not have readymade answer. Hence the women in India have to struggle in utilizing her managerial skills in managing the family resources. Household management is known as the effective use of resources on the development of family members and their satisfaction. All the women are not born with managerial qualities but they can learn through observation and training.

It is a universally accepted fact that knowledge is power. The emerging knowledge and technology become the strategic resources for accelerating the pace of advancement. This signifies the paramount importance of speedy and effective transfer of available knowledge and technology to the users (Singh, 1997). The manager ultimately women should be perfect in management to lead successful family life.

Keeping in view the paramount importance of managerial skill in effective utilization of resources it was felt necessary to identify the training needs of rural women in this area and train them for better management.

Hence, the present investigation was undertaken in two phases. In first phase problems and training needs of rural women with regard to household managerial skills were identified. In second phase the need based training package was developed and administered on selected women through participatory method.

\section{Materials and Methods}

\section{Locale of study}

The present investigation was carried out in four villages i.e. Nandkheda, Brahmangaon, Sayala and Lohagaon of Marathwada region. A total sample of 100 women 25 each from four villages were selected randomly.

\section{Collection of data}

The various problems experienced by rural women while handling the household responsibilities were recorded through group discussions \& participatory brain storming sessions. The focus was on varied problems faced while handling the household responsibilities. The experiences explicitly acknowledged as problems and listed through multiple perceptions on different aspects. The selected statements were grouped under various areas of management.

\section{Assessment of difficulty score}

The responses of selected homemakers for enlisted managerial aspects were recorded on the 3-point scale indicating the responses as difficult, Neutral, and easy to assess difficulty score with corresponding values of 3,2 and 1 . The schedule was administered through participatory interview among selected rural homemakers.

\section{Developing the training package on managerial skills}

In the second phase of research based on the rural homemaker's requirement a managerial training package was developed. The developed training package comprised seven broad areas of Family Resource Management such as 1) Qualities of good homemaker, 2) Life cycle stages, 3) Resource utilization pattern, 4) Management of time, 5) Management of money, 6) Management of human energy and 7) Decision making process.

\section{Intervention Programme}

The intervention was carried out with an intensive training to selected rural women for one month through theoretical models, lectures cum demonstration, illustrative charts 
and skits followed by interactive sessions with homemakers.

\section{Impact analysis of managerial intervention package}

Pretesting for awareness regarding the managerial practices of selected homemakers was carried out before starting the training programme. The awareness score of homemakers was calculated by dividing the known tips with exposed tips \& multiplying it by 100 . The awareness score was recorded before \& after the intervention of training package to assess the impact of training. The utility perception score was assessed by collecting the responses of selected homemakers regarding usefulness \& applicability of each aspect included in managerial intervention package on three point summated rating scale after the intervention programme.

\section{Statistical Analysis}

The collected data were analyzed statistically by applying Correlation coefficient test \& Analysis of variance technique (Sharma, 2005).

\section{Results and Discussion}

The general information of rural homemakers is illustrated in Table 1. It is clear from the table that majority of the rural homemakers were school educated $(56 \%)$ between the age group of 31-45 years $(55 \%)$, married at the age of $18-25$ years $(56 \%)$ and had $10-20$ years experience $(36 \%)$ of married life. The annual income of the family was recorded between Rs.50, 000-1, 00,000 by 43 per cent of families.

The areas of managerial difficulties experienced by rural women $\&$ difficulty score are presented in table2. It is clear from the table that almost all the rural women expressed that they have either kind of problem in managing time, energy, and money \& maintaining inter-personal relations in the family. Only 57 per cent women expressed problem regarding role performance with regard to some of the household activities. The percentage difficulty score was found to be more in the area of money management (44.94\%) followed by time management (41.58\%). The difficulty score of managing the fatigue was 38.61 per cent followed by managing the inter- personal relations with family members $(30.46 \%)$. Percentage difficulty score for role performance was noted as 26.43 per cent. Statistical analysis revealed significant variation between the difficulty scores experienced by the homemakers in the areas of management of various household responsibilities. This indicated that money constraints were more followed by time \& energy constraints.

Table 3 indicates the correlation between difficulty score \& demographic variables of homemakers. It was observed from the findings that the age of homemaker was positively correlated with difficulty score of money management \&interpersonal relationship with family members. This may be due to the reason that as age increases the responsibilities also increase and there may be problem with money management. Further due to increasing age the rigidity increases or sometimes due to more age more negative experiences with other family members may sometimes lead to difficulty in adjusting with people and causing strenuous relationship. Whereas education was correlated negatively with problems related to energy, money \& interpersonal relations. This indicates that education empowers women with knowledge and leads to ease in management of resources and people. Age at the marriage of rural women was having negative correlation with difficulty score of money management. 
Table.1 General Information of rural homemakers.

\begin{tabular}{|c|c|}
\hline Attributes of homemaker & Frequency \& percentage of home makers \\
\hline Age group(yrs) & \\
\hline $16-30$ & 41 \\
\hline $31-45$ & 55 \\
\hline$>45$ & 4 \\
\hline Age at Marriage (yrs) & 44 \\
\hline $11-17$ & 56 \\
\hline $18-25$ & \\
\hline Annual Income of family (Rs) & 35 \\
\hline $20,000-50,000$ & 43 \\
\hline $50,000-1,00,000$ & 22 \\
\hline$>1,00,000$ & \\
\hline Experience of married Life (yrs) & 8 \\
\hline$<1$ year & 25 \\
\hline Up to 10 yrs & 36 \\
\hline $10-20$ yrs & 31 \\
\hline$>20$ yrs & \\
\hline Education level & 2 \\
\hline Illiterate & 59 \\
\hline School educated & 39 \\
\hline College educated & \\
\hline
\end{tabular}

Table.2 Managerial difficulties experienced by rural women and difficulty perception score

\begin{tabular}{|c|c|c|c|}
\hline Managerial aspects & \% of rural women & $\begin{array}{c}\text { Mean difficulty } \\
\text { score }\end{array}$ & \% difficulty score \\
\hline Time & 100 & 14.97 & 41.58 \\
\hline Energy & 100 & 10.04 & 38.61 \\
\hline Money & 100 & 7.19 & 44.94 \\
\hline Inter personal relations & 95 & 7.92 & 30.46 \\
\hline Role performance & 57 & 3.70 & 26.43 \\
\hline F=45.39** Significantat 1 percent
\end{tabular}

Table.3 Correlation between managerial difficulty score \& demographic variables of rural women

\begin{tabular}{|c|c|c|c|c|c|}
\hline $\begin{array}{c}\text { Managerial } \\
\text { Difficulties }\end{array}$ & Age & $\begin{array}{c}\text { Educatio } \\
\mathrm{n}\end{array}$ & $\begin{array}{c}\text { Age at } \\
\text { Marriage }\end{array}$ & $\begin{array}{c}\text { Experience of Married } \\
\text { life }\end{array}$ & $\begin{array}{c}\text { Annual } \\
\text { income }\end{array}$ \\
\hline Time & $-0.12 \mathrm{NS}$ & $0.09 \mathrm{NS}$ & $0.16 \mathrm{NS}$ & $-0.15 \mathrm{NS}$ & $-0.28^{* *}$ \\
\hline Energy & $0.15 \mathrm{NS}$ & $-0.27^{* *}$ & $-0.12 \mathrm{NS}$ & $0.18 \mathrm{NS}$ & $-0.33^{* *}$ \\
\hline Money & $0.24^{*}$ & $-0.29^{* *}$ & $-0.20^{*}$ & $0.37^{* *}$ & $-0.001 \mathrm{NS}$ \\
\hline Interpersonal Relations & $0.26^{* *}$ & $-0.34^{* *}$ & $-0.1 \mathrm{INS}$ & $0.30^{* *}$ & $-0.23^{*}$ \\
\hline Role Performance & $0.001 \mathrm{~N}$ & $-0.12 \mathrm{NS}$ & $0.006 \mathrm{NS}$ & $-0.06 \mathrm{NS}$ & $-0.27^{* *}$ \\
\hline
\end{tabular}

NS Non significant. * Significant at 5 per cent ** Significant at 1 per cent. 
Table.4 Training needs regarding household management as expressed by rural women

\begin{tabular}{|c|c|}
\hline Need based training areas & \% of rural women \\
\hline Time Management & 75 \\
\hline Life cycle requirement & 67 \\
\hline Fatigue management & 62 \\
\hline Money Management & 47 \\
\hline Inter personal relations & 45 \\
\hline
\end{tabular}

Table.5 Awareness regarding various managerial aspects before $\&$ after the intervention programme

\begin{tabular}{|c|c|c|c|}
\hline Managerial Aspects & \multicolumn{2}{|c|}{$\begin{array}{c}\text { Percent awareness of Rural Women } \\
\text { Mean } \pm \text { SD }\end{array}$} & $\mathbf{Z}^{\prime}$ Value \\
\hline & $\begin{array}{c}\text { Before } \\
\text { training }\end{array}$ & $\begin{array}{c}\text { After training } \\
\end{array}$ & \\
\hline Resources & $29.86 \pm 16.13$ & $94.00 \pm 7.91$ & $3,57^{* *}$ \\
\hline Life cycle stages & $26.67 \pm 25.07$ & $100 \pm 0.00$ & $2.92^{*}$ \\
\hline Time & $24.54 \pm 4.18$ & $94.45 \pm 7.41$ & $8.21^{* *}$ \\
\hline Money & $18.82 \pm 2.36$ & $93.76 \pm 6.83$ & $10.36^{* *}$ \\
\hline Energy & $17.33 \pm 5.36$ & $92.00 \pm 8.26$ & $7.58^{* *}$ \\
\hline Decision making & $33.33 \pm 0.00$ & $88.00 \pm 3.03$ & $3.03^{* *}$ \\
\hline Qualities of Homemaker & $25.00 \pm 0.00$ & $93.37 \pm 8.96$ & $7.63^{* *}$ \\
\hline
\end{tabular}

*Significant at 5 per cent

** Significant at 1 per cent

Table.6 Correlation between demographic variables of rural women \& mean awareness score of rural women after intervention of training package.

\begin{tabular}{|c|c|c|c|c|c|}
\hline $\begin{array}{c}\text { Demographic } \\
\text { Variables } \\
\text { Managerial } \\
\text { Aspects }\end{array}$ & Age & Education & $\begin{array}{c}\text { Type of } \\
\text { family }\end{array}$ & $\begin{array}{c}\text { Family } \\
\text { size }\end{array}$ & $\begin{array}{c}\text { Experience of } \\
\text { married life }\end{array}$ \\
\cline { 2 - 6 } & $-0.03 \mathrm{NS}$ & $0.21^{*}$ & $0.18 \mathrm{NS}$ & $-0.02 \mathrm{NS}$ & $0.54^{* *}$ \\
\hline Resources & $0.56^{* *}$ & $-0.02 \mathrm{NS}$ & $-0.17 \mathrm{NS}$ & $-0.18 \mathrm{NS}$ & $-0.03 \mathrm{NS}$ \\
\hline Life cycle stages & $0.97^{* *}$ & $0.55^{* *}$ & $0.02 \mathrm{NS}$ & $-0.16 \mathrm{NS}$ & $-0.18 \mathrm{NS}$ \\
\hline Time & $-0.05 \mathrm{NS}$ & $-0.14 \mathrm{NS}$ & $0.02 \mathrm{NS}$ & $-0.04 \mathrm{NS}$ & $-0.05 \mathrm{NS}$ \\
\hline Money & $-0.12 \mathrm{NS}$ & $0.16 \mathrm{NS}$ & $-0.10 \mathrm{NS}$ & $-0.06 \mathrm{NS}$ & $-0.13 \mathrm{NS}$ \\
\hline Energy & $0.03 \mathrm{NS}$ & $-0.02 \mathrm{NS}$ & $0.10 \mathrm{NS}$ & $0.08 \mathrm{NS}$ & $0.07 \mathrm{NS}$ \\
\hline Decision making & $0.16 \mathrm{MS}$ & $0.26^{* *}$ & $0.03 \mathrm{NS}$ & $-0.03 \mathrm{NS}$ & $0.19^{*}$ \\
\hline $\begin{array}{c}\text { Qualities of } \\
\text { Homemaker }\end{array}$ & & & & & \\
\hline
\end{tabular}

NS Non significant. * Significant at 5 per cent ** Significant at 1 per cent 
Table.7 Utility perception score of managerial intervention package

\begin{tabular}{|c|c|c|c|}
\hline \multirow{2}{*}{ Managerial Aspects } & \multicolumn{3}{|c|}{ Utility perception score } \\
\cline { 2 - 4 } & Maximum & Mean & Percentage \\
\hline Resources & 21 & 19.35 & 92.14 \\
\hline Life cycle stages & 9 & 9.00 & 100 \\
\hline Time & 39 & 34.6 & 88.72 \\
\hline Money & 48 & 25.5 & 53.12 \\
\hline Energy & 45 & 35.4 & 78.67 \\
\hline Decision making & 9 & 7.4 & 82.22 \\
\hline Qualities of \\
Homemaker & 24 & 20.75 & 86.46 \\
\hline
\end{tabular}

Experience of married life was positively correlated with difficulty score of rural women in the area of money \& interpersonal relations. Annual income of family exerted negative correlation with difficulty score in managing human energy; inter personal relations \& role performance of rural women. This indicates that ample money resource reduces many managerial problems in family.

Felt need of the trainings expressed by rural women is presented in table 4. More than 60 percent rural women expressed the necessity of training in the area of managing skill in time, life cycle stages \& fatigue. More than 45 per cent rural women expressed the necessity of training in the area of money management \& Interpersonal relations.

The awareness regarding selected managerial practices by participant rural women was recorded before \& after the intervention programme $\&$ is presented in table 5 . It is clear from the table that the percent awareness of rural women had drastically increased for all managerial aspects covered under training. The awareness of home makers regarding availability \& utilization of resources $(94 \%)$, Concept of life cycle stages (100\%), time $(94.45 \%)$, money $(93.76 \%)$, Utilization of human energy (92\%), decision making process (88\%) \& qualities of homemaker (93.37\%) was found to be increased after implementing the intervention programme. The comparative assessment of awareness score before \& after the training with application of ' $\mathrm{Z}$ ' test revealed significant increase in awareness of rural women regarding all the managerial aspects covered in training programme.

The correlation between post training awareness score was correlated with demographic variables of trainees $\&$ presented in table 6. It is clear from the table that there was positive correlation between age and awareness score regarding concept $\&$ resource utilization in various stages of life cycle $(\mathrm{r}$ $\left.0.56^{* *}\right)$ and concept \& managerial tips for time utilization pattern $(\mathrm{r}-0.97 * *)$. Educational level showed positive correlation between awareness score regarding managerial tips for resource utilization $(\mathrm{r}=$ $0.21 *$ ), qualities of good homemakers ( $\mathrm{r}$ $\left.0.26^{*}\right)$ and time utilization pattern $(\mathrm{r}=$ $\left.0.55^{* *}\right)$. Experience of married life exhibited positive correlation with awareness score regarding resource utilization and qualities of good homemaker.

The utility perception score of managerial training intervention package of rural women is presented in table 7. It is clear from the table that rural women have perceived higher utility (ranging between $78.67 \& 100 \%$ ) of training package to improve quality of life. Money managerial aspects included in the 
package have perceived less useful (53.12\%) as they were not having independence in management of money.

The study that the rural women face the problem in managing family resources and need training help to empower themselves with managerial skills in selected areas of household management. The developed training package improved the awareness of majority of the rural homemakers regarding the selected managerial aspect such as optimizing the use of human \&non-human resources, resource utilization \& life cycle stages, time, money \& energy management, decision making process in family life and qualities of homemakers, Correlation coefficient test revealed that older women with higher education \& more experience of married life gained more knowledge on selected managerial aspects such as resource utilization pattern, time management \& qualities of homemakers this may be attributed to their life experiences. Utility perception score on managerial intervention package revealed that the managerial intervention package is useful for rural homemakers to enhance the quality of their family life.

\section{References}

Mann, M. K. (1984) Home Management. Home Management for Indian Families, Kalyani publishers, New Delhi pp1-3

Sharma, H. L. (2005) Basic Statistical Methods with Applications. Agrotech publishing academy Udaipur PP 304307

Singh B. (1997) Training Manual of Short course on advanced training technology pp-1-3.

\section{How to cite this article:}

Madhuri Kulkarni, Jayashri Rodge and Manjusha Revanwar. 2021. Impact Analysis of Developed Managerial Intervention Package. Int.J.Curr.Microbiol.App.Sci. 10(06): 393-399. doi: https://doi.org/10.20546/ijcmas.2021.1006.041 